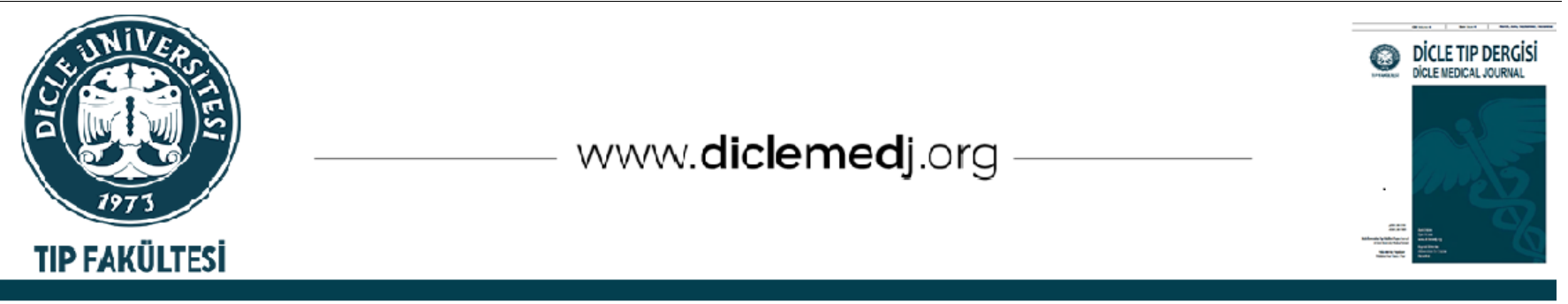

Original Article / Özgün Araştırma

\title{
Copeptin levels are more elevated and associated with cardiovascular events in the unity of chronic ischemic heart and chronic kidney diseases
}

\author{
Yusuf Türkmen ${ }^{1}$, Naci Babat ${ }^{D_{1}}$ \\ 1 Van Yuzuncu Yil University, School of Medicine, Department of Cardiology Van, Turkey
}

Received: 14.08.2020; Revised: 27.10.2020; Accepted: 02.11.2020

\begin{abstract}
Objective: Copeptin comprises the C-terminal part of the Arginine vasopressin (AVP) precursor, is co-secreted with AVP and is a stable surrogate marker for AVP release, making it much easier to measure. Elevated levels of serum copeptin in both cardiovascular and renal diseases were known but the amount and predictive value of copeptin in the unity of these diseases is unknown.

Methods: A study composed equally divided five groups, total of 150 adult patients. Group I and group II composed study groups which included the patients of chronic ischemic heart (CHID) and chronic kidney diseases (CKD) respectively. Control groups such as group III, IV and V included only patients of CHID or CKD. Copeptin, hs-CRP and pro-BNP levels were analyzed in all patients and their relationship with adverse outcomes were evaluated.

Results: Serum levels of copeptin, hs-CRP and pro-BNP were higher in patients of study groups than patients of control groups and it was found statistically meaningful $(\mathrm{p}<.05)$. Cardiovascular and all-cause mortality which defined as primary end points were similar in study and control groups but secondary end points such as re-hospitalization ( $\mathrm{p}=.001$ for group I and $\mathrm{p}=.026$ for group II) and arrhythmias ( $\mathrm{p}=.003$ for group I and $\mathrm{p}=.001$ for group II) were higher in the patients of study group.
\end{abstract}

Conclusion: More elevated levels of copeptin in patients of study group couldn't predict primary end points but it predicts some of secondary end points such as re-hospitalization and arrhythmias.

Keywords: copeptin, chronic kidney disease, chronic ischemic heart disease

DOI: 10.5798/dicletip.850390

Correspondence / Yazıșma Adresi: Naci Babat, Department of Cardiology School of Medicine, Van Yuzuncu Yil University, 65500 Van, Turkey e-mail: nacibabat@hotmail.com 


\section{Kronik İskemik Kalp ve Kronik Böbrek Yetmezliği Hastalıklarının Birlikteliğinde Kopeptin Düzeyi Çok Daha Yüksek ve Kardiyovasküler Olaylarla İlişkilidir}

Öz

Giriș: Kopeptin, Arjinin vasopressinin (AVP) C-terminal kısmını oluşturur ve oda sıcaklığında stabil olduğundan serumdaki düzeyini belirlemede kolaylık sağlar. Hem kardiyovasküler hem de böbrek hastalıklarında yüksek kopeptin düzeyinin olumsuz olayları ön görücülüğü bilinmekte ise de bu iki hastalığın birlikteliğinde kopeptin düzeyinin ne kadar yüksek olduğu ve olumsuz olayları ön görücülüğü bilinmemektedir.

Yöntemler: Çalışmaya toplam 150 hasta dahil edilmiş olup 5 eşit gruba bölünmüşlerdir. Grup 1 kronik iskemik kalp hastalarını, grup 2 ise kronik böbrek hastalarını ihtiva etmektedir. Grup 3,4 ve 5 kontrol grubunu oluşturmaktadır. Tüm hastaların kopeptin, hs-CRP ve pro-BNP düzeyleri ölçülerek olumsuz sonuçlar ile ilişkileri değerlendirilmiştir.

Bulgular: Çalışma grubu hastalarında kopeptin, pro-BNP ve hs-CRP düzeyleri kontrol grubuna göre istatistiksel olarak daha yüksek bulundu $(\mathrm{p}<.05)$. Primer sonlanım noktası olan kardiyovasküler ve tüm nedenli ölümler tüm gruplarda aynı olsa da yeniden hastaneye yatış ( $\mathrm{p}=.001$ grup I ve $\mathrm{p}=.026$ grup II için) ve aritmiler çalışma grubu hastalarında daha yüksek bulundu ( $\mathrm{p}=.003$ grup I ve $\mathrm{p}=.001$ grup II için).

Sonuç: Çalışma grubu hastalarındaki yüksek kopeptin düzeyleri primer sonlanım noktası açısından öngörücü değil ise de yeniden hastaneye yatış ve aritmiler gibi bazı ikincil sonlanım noktalarını ön görücülüğü mevcuttur.

Anahtar kelimler: kopeptin, kronik iskemik kalp hastalığı, kronik böbrek hastalığı.

\section{INTRODUCTION}

Arginine vasopressin (AVP), also known as antidiuretic hormone which releases from a hypothalamus in response to changes in plasma osmolality and arterial hypovolemia. It regulates fluid volume and serum osmolality. The measurement of AVP level is difficult because of its pre-analytical instability in room temperature. Copeptin, a 39-amino acid glycopeptide that comprises the $\mathrm{C}$-terminal part of the AVP precursor, is co-secreted with AVP from the neurohypophysis and is a stable surrogate marker for AVP release, making it much easier to measure ${ }^{1}$. Reichlin and Müller studied the role of copeptin in the management of patients with chest pain presenting to the emergency department (ED). In those patients copeptin levels were already elevated 0 to 4 hours after the onset of symptoms, at a time when troponin $\mathrm{T}$ was still undetectable in many patients ${ }^{2}$. Additionally, copeptin values were higher after acute MI and in heart failure patients and associated with poor prognosis ${ }^{3}$. However, long-term elevated levels of copeptin and its association with adverse outcomes in chronic ischemic heart disease is unknown.

Cardiovascular diseases are a leading cause of mortality and morbidity in renal failure patients. Electrolyte disturbances and albuminuria are common in cardiovascular and renal diseases. Both of them are associated with elevated serum copeptin levels and poor prognosis ${ }^{4-6}$. Elevated levels of copeptin in separately cardiovascular and renal diseases is known but the amount of serum copeptin levels is unknown in the unity of cardiovascular and renal diseases. Is it more elevated in the serum and related with more adverse outcomes on the latest situation? All of these questions were reason of our study.

\section{METHODS}

A total of 150 adult patients (50 women) were included to the current study. While the first two groups consisted, study group the other three groups consisted control group. Group I and group II included the patients of both chronic ischemic heart (CHID) and chronic kidney diseases (CKD) and all patients in group 
II were treated by hemodialysis. Group III, IV and $\mathrm{V}$ composed control patients and each group included 30 patients. Group III and IV included only CKD patients who were not required and required to hemodialysis respectively. Additionally, group V covered only the patients of chronic ischemic heart disease (CHID).

A stenosis more than $70 \%$ angiographically and demonstration of ischemia in any region of myocardium in scintigraphy were accepted as sufficient for the diagnosis of CHID. Glomerular filtration rate (GFR) values were calculated by Cockroft-Gault equation and the patients with lower levels of GFR $(60$ milliliter/minute $/ 1.73 \mathrm{~m} 2$ ) were diagnosed with CKD. Either the presence of acute renal failure or acute coronary syndrome were the criteria of exclusion from the study. The trial protocol was approved by the local Ethics Committees and informed written consent of all patients was obtained before to enroll the study. Ethics committee permission was given in 2012 by the Istanbul No 1 Clinical Research Ethics Committee under the number A26.

Blood samples of all patients have taken and urea, creatinine, potassium, total cholesterol, high density lipoprotein (HDL), low density lipoprotein (LDL), triglycerides (TG), glucose, uric acid, creatine clearance, whole blood count, high sensitive C-reactive protein (hs-CRP), pro brain natriuretic protein (pro-BNP) and copeptin levels were analyzed.

Abcam's CRP Human ELISA (Enzyme-Linked Immunosorbent Assay) kit, Abcam's Anti-BNP antibody kit and ELISA Kit for Human Copeptin (Uscn Life Science Inc., Wuhan, China) were used in the determination of hs-CRP, pro-BNP and copeptin levels respectively.

The functional and anatomic features of left ventricle such as ejection fraction (LVEF), diastolic dysfunction parameters and diameters were also measured and recorded. Additionally, the relation of Gensini score with copeptin levels also evaluated. Primary end points of study were cardiac and all-cause mortality. Secondary end points were cardiovascular rehospitalization, myocardial infarction, stroke and cardiac arrhythmias. All patients have followed at least 6 months and relation of serum copeptin, pro BNP and hs-CRP levels with primary and secondary end points were investigated in the patients of both study and control groups.

\section{Statistical Analysis}

Mean, standard deviation, median, minimum and maximum values were used for definitive statistics of data. Kruskal-Wallis/MannWhitney $U$ test was used in the analyzation of non-parametric and parametric quantitative data. ROC curves were used to detect the correlations and effectiveness levels of copeptin, hs CRP, and pro-BNP. P value $<0.05$ was considered statistically significant. All statistical analyses were performed using the SPSS statistical package for Windows, version 21.0 (SPSS, Inc., Chicago, Ill., USA).

\section{RESULTS}

Average ages of patients in groups I to group $\mathrm{V}$ were $60.1,65.5,67.0,62.4$ and 56.3 years respectively. Patients in group II and III was found statistically older than the patients in group IV and V $(\mathrm{p}<.05)$. There wasn't any difference in terms of gender. The demographic features of the patients were shown in table 1 . Serum levels of copeptin, hs-CRP and pro-BNP were summarized in table 2 as shown below. They were higher in patients of study groups than the patients of all control groups $(\mathrm{p}<.05)$. Although there was a meaningful correlation of copeptin levels with NYHA class $(\mathrm{p}=.004)$, hsCRP $\left(p^{=} .01\right)$ and pro-BNP $\left(p^{=} .011\right)$ in group I. Cardiovascular and all-cause mortality which were defined as primary end points were similar in study and control but secondary end points such as cardiovascular re-hospitalization 
( $p=.001$ for group I and $p^{=} .026$ for group II) and arrhythmias $\left(p^{=} .003\right.$ for group I and $p^{=} .001$ for group II) were higher in group I and group II than others at the end of sixth month follow-up.

Table I: The demographic features and the presence of co-morbid diseases in patients of both study and control groups

\begin{tabular}{|llll|}
\hline Variable & Study & Control & P value \\
\hline Age (years) & $62.8 \pm 16.8$ & $61.9 \pm 17.9$ & 0.89 \\
Cardiovascular co-morbidities & & & \\
Hypertension & $33(55 \%)$ & $43(48 \%)$ & 0.09 \\
Ischemic heart disease & $42(70 \%)$ & $30(33 \%)$ & $<0.001$ \\
Heart failure & $16(27 \%)$ & $5(6 \%)$ & $<0.001$ \\
Valvular diseases & $1(2 \%)$ & $1(1 \%)$ & 0.65 \\
Pulmonary hypertension & $1(1 \%)$ & 0 & 0.52 \\
\hline
\end{tabular}

Table II: Comparison of serum copeptin, hsCRP and proBNP levels in groups.

\begin{tabular}{|c|c|c|c|c|c|}
\hline & & Mean \pm S.D & Median & $\begin{array}{l}\text { Min- } \\
\text { Max }\end{array}$ & $\mathrm{P}$ \\
\hline & Group I & $20,0 \pm 9,2 * \S \#$ & 21,7 & $3,7-41,5$ & \\
\hline & Group II & $19,1 \pm 12,8 * \S \#$ & 17,5 & $2,9-42,9$ & \\
\hline \multirow{5}{*}{$\begin{array}{l}\text { Copepetin } \\
0,0001\end{array}$} & Group III & $6,1 \pm 4,7 \S$ & 4,1 & $1,1-20,3$ & \\
\hline & Group IV & $11,6 \pm 10,8 *$ & 6,2 & $1,1-39,1$ & \\
\hline & Group V & $4,4 \pm 3,3$ & 4,0 & $1,0-16,4$ & \\
\hline & Group I & $9,9 \pm 5,9 * \S \#$ & 8,9 & $1,3-26,2$ & \\
\hline & Group II & $12,2 \pm 12,3$ *§\# & 12,0 & $1,3-60,8$ & \\
\hline \multirow[t]{5}{*}{$\begin{array}{l}\text { hsCRP } \\
0,0001\end{array}$} & Group III & $2,8 \pm 2,5 *$ & 1,7 & $1,0-12,1$ & \\
\hline & Group IV & $6,1 \pm 6,2 * \#$ & 2,7 & $1,0-24,5$ & \\
\hline & Group V & $2,1 \pm 1,3$ & 1,7 & $1,0-7,4$ & \\
\hline & Group I & $841,9 \pm 721,8$ *\$\# & 666 & $210-3500$ & \\
\hline & Group II & $679,9 \pm 519,1 * \S \#$ & 551 & $153-2181$ & \\
\hline \multirow[t]{3}{*}{$\begin{array}{l}\text { proBNP } \\
0,0001\end{array}$} & Group III & $251,2 \pm 180,9$ & 201 & $86-925$ & \\
\hline & Group IV & $363,7 \pm 335,7$ * & 266 & $75-1369$ & \\
\hline & Group V & $192,2 \pm 151,8$ & 172 & $19-710$ & \\
\hline
\end{tabular}

Kruskal-wallis (Mann-whitney $u$ test) ${ }^{*}: p<0.05$ according to group $V$, $\S: p<0.05$ according to group IV, \#:p<0.05 according to group III S.D: Standart Deviation, Min-Max: Minimum-Maximum

Likewise, in addition to copeptin ( $\left.p^{=} .008\right)$, hsCRP $(p=.011)$ was also predicts occurrence of arrhythmias but not pro-BNP $\left(p^{=} .06\right)$ in group I. Area under curve (AUC) for hs-CRP was greater than the AUC for copeptin. In group II all of these three biomarkers were able to predict occurrence of arrhythmias. It was shown in figure 1.

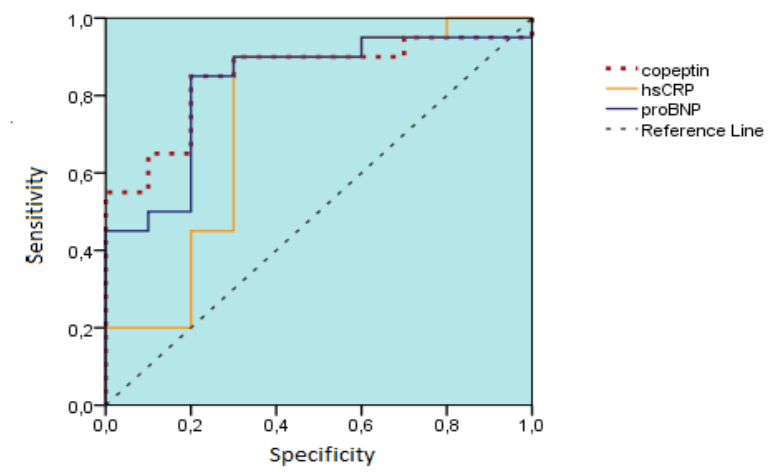

Figure 1. ROC curve of effectiveness of copeptin, hsCRP and proBNP in group II for prediction of arrhythmia

Copeptin and pro-BNP, but not hs-CRP predict cardiovascular re-hospitalization in both study groups. Minimum and maximum areas under the curve for copeptin, pro-BNP and hs-CRP were 0.824 to $1(\mathrm{p}=.001), 0,749$ to $1(\mathrm{p}=.002)$, and 0.665 to $0,912(p=.174)$ in group I. It was represented in figure 2 .

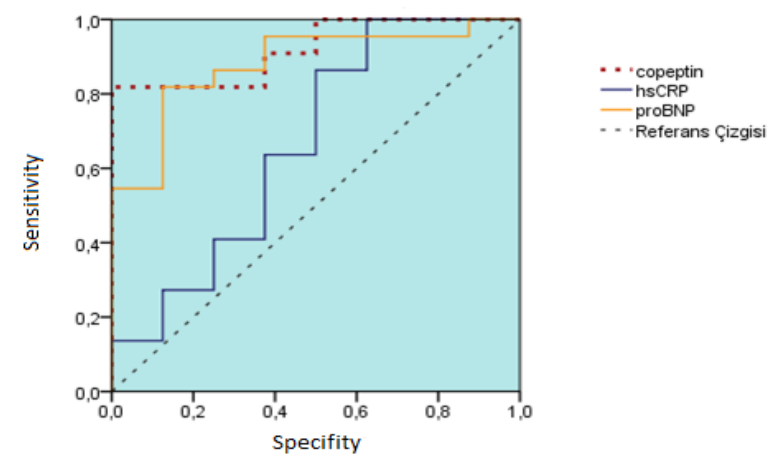

Figure 2. ROC curve of effectiveness of copeptin, hsCRP and proBNP in group I for prediction of cardiac rehospitalizatin.

Also, areas under curve for the patients of group II in ROC analyze were 0.826 to $1(\mathrm{p}=.015)$, 0.694 to $1(\mathrm{p}=.147)$ and 0,668 to $1(\mathrm{p}=.011)$. 
However, there wasn't any prediction value of copeptin for myocardial infarction $(\mathrm{p}=.465)$ and stroke $(\mathrm{p}=.96)$ in both study groups of patients.

\section{DISCUSSION}

Recent studies showed that both copeptin and vasopressin give similar responds to kinetic increasing or decreasing of plasma osmolality ${ }^{7}$. The importance of copeptin in diagnosis and treatment of both cardiovascular and other diseases has exhibited with various trials ${ }^{8}$. Gobeaux et al. ${ }^{9}$ were investigated predictive value of copeptin on the early period of chest pain and they found that copeptin aids on the excluding of myocardial infarction. Better relationship of copeptin than troponin with a short-term mortality and morbidity (cardiovascular re-hospitalization, stroke) on coronary artery disease patients were showed by Von Haehling et al ${ }^{10}$. Copeptin was an accurate predictor of re-hospitalization in our study also. Additionally, we were investigated relationship of serum copeptin levels with a Gensini score, which represents severity of coronary artery disease, but there wasn't any relation perhaps due to the minority of patients in groups. Chai et al. ${ }^{11}$ demonstrated $60 \%$ of elevation in copeptin levels after 24-hour of elective PCI and there was relationship of elevated serum copeptin levels with an elevated diastolic blood pressure. Copeptin was related with NYHA class, pro-BNP and hs-CRP in our study group patients who diagnosed with chronic ischemic heart disease and treated with hemodialysis. We supposed that increasing of inflammation in coronary arteries, enhanced sympathetic activity and vasoconstriction in these patient groups trigger left ventricular wall stress and increase serum vasopressin and copeptin levels. One another study showed that elevated copeptin levels were associated with increased mortality and re-hospitalization in long term follow-up ${ }^{12}$. We have detected the similar result in the field of re-hospitalization in our study as well. Leading cause of re- hospitalization was a decompensated heart failure. Elevated pro-BNP levels, additional to copeptin was also describes and supports the reason of re-hospitalization for sure. Xin et al. ${ }^{13}$ revealed that BNP and copeptin levels were significantly higher in the patients of CKD than patients of control group. GFR, intima-media thickness, left ventricular hypertrophy and history of cardiovascular disease were affected serum copeptin and BNP levels in their study. Similarly, serum copeptin, pro-BNP and hs-CRP levels were higher in the unity of chronic ischemic heart and chronic kidney disease patients in our study. However, there wasn't any relationship with copeptin and echocardiographic parameters particularly such as ejection fraction. On the other hand, Fenske et al. ${ }^{14}$ investigated serum level of copeptin in patients of diabetic nephropathy who were treated with hemodialysis. Higher quartile of copeptin was associated with 3.5fold of stroke, 1.73-fold of sudden cardiac death, 1.42 -fold of combined cardiovascular events and 1.48-fold of all-cause mortality but relation with elevated serum copeptin levels and mortality risk due to myocardial infarction and heart failure wasn't meaningful. We were also determined increased rate of re-hospitalization and serious arrhythmias in our study group patients but predictive value of copeptin in stroke and myocardial infarction wasn't meaningful.

Elevated levels of copeptin in cardiovascular and renal diseases were known but the amount and predictive value of copeptin in the unity of chronic ischemic heart disease and chronic kidney disease patients (study group) has still unknown. Present trial demonstrated that more elevated serum levels of copeptin, pro-BNP and hs-CRP were detected in the patients of study group than in the patients of chronic ischemic heart or chronic kidney disease patients separately. Furthermore, we have investigated the predictive value of elevated copeptin levels 
in patients of study group. More elevated levels of copeptin couldn't predicts primary end points but it predicts some of secondary end points such as re-hospitalization and arrhythmias. However, other secondary end points such as stroke and myocardial infarction were also not predicted by elevated levels of copeptin.

Ethics Committee Approval: The trial protocol was approved by the local Ethics Committees and informed written consent of all patients was obtained before to enroll the study. Ethics committee permission was given in 2012 by the Istanbul No 1 Clinical Research Ethics Committee under the number A26.

Declaration of Conflicting Interests: The authors declare that they have no conflict of interest.

Financial Disclosure: No financial support was received.

\section{REFERENCES}

1. Morgenthaler NG, Struck J, Alonso C, Bergmann A. Assay for the measurement of copeptin, a stable peptide derived from the precursor of vasopressin. Clin Chem 2006; 52: 112-9.

2. Reichlin T, Hochholzer W, Stelzig C, et al. Incremental value of copeptin for rapid rule out of acute myocardial infarction. J Am Coll Cardiol. 2009; 54: 60-8.

3. Khan SQ, Dhillon OS, O'Brien RJ, et al. C-terminal provasopressin (copeptin) as a novel and prognostic marker in acute myocardial infarction: Leicester Acute Myocardial Infarction Peptide (LAMP) study. Circulation 2007; 115: 2103-10.

4. Vachharajani TJ, Zaman F, Abreo KD. Hyponatremia in critically ill patients. J Intensive Care Med. 2003; 18: 3-8.

5. Bardoux P, Bichet DG, Martin H, Gallois y, Marre m. Vasopressin increases urinary albumin excretion in rats and humans: involvement of V2 receptors and the renin-angiotensin system. Nephrol Dial Transplant. 2003; 18: 497-506.
6. Fernandes S, Bruneval P, Hagege A, et al. Chronic V2 vasopressin receptor stimulation increases basal blood pressure and exacerbates deoxycorticosterone acetate-salt hypertension. Endocrinology 2002; 143: 2759-66.

7. Szinnai G, Morgenthaler NG, Berneis K, et al. Changes in plasma copeptin, the C-terminal portion of arginine vasopressin during water deprivation and excess in healthy subjects. J Clin Endocrinol Metab. 2007; 92: 3973-8.

8. Morgenthaler NG, Müller B, Struck J, et al. Copeptin, a stable peptide of the arginine vasopressin precursor, is elevated in hemorrhagic and septic shock. Shock 2007; 28: 644-9.

9. Chenevier-Gobeaux C, Freund Y, Claessens YE, et al. Copeptin for rapid rule out of acute myocardial infarction in emergency department. Int J Cardiol 2013; 166: 198-204.

10. Von Haehling S, Papassotiriou J, Morgenthaler $\mathrm{NG}$, et al. Copeptin as a prognostic factor for major adverse cardiovascular events in patients with coronary artery disease. Int J Cardiol 2012; 162: 2732.

11. Chai SB, Hui YM, Li XM, Xiao Y, Tang CS. Plasma levels of copeptin in patientswith coronary heart disease. Heart Vessels 2009; 24: 79-83.

12. Keller T, Blankenberg S. Copeptin improves early diagnosis of acute myocardial infarction. Circulation 2009; 120: 1035.

13. Li X, Yang XC, Sun QM, Chen XD, Li YC. Brain natriuretic peptide and copeptin levels are associated with cardiovascular disease in patients with chronic kidney disease. Chin Med J (Engl) 2013; 126: 823-7.

14. Fenske W, Wanner C, Allolio B, et al. Copeptin levels associate withcardiovascular events in patients with ESRD and type 2 diabetes mellitus. J Am Soc Nephrol 2011; 22: 782-90. 